\title{
Significance of bioactive compounds, therapeutic and agronomic potential of non-commercial parts of the Coffea tree
}

\author{
Importancia de los compuestos bioactivos, potencial terapéutico y agronómico de las partes \\ no comerciales del árbol del cafeto
}

\begin{abstract}
Mayra Cristina Rosales-Villarreal', Nuria Elizabeth Rocha-Guzmán', José Alberto Gallegos-Infante', Martha Rocío Moreno-Jiménez', Rosalía Reynoso-Camacho², Iza Fernanda Pérez-Ramírez², Rubén Francisco González-Laredo ${ }^{1 *}$

1 Tecnológico Nacional de México-Instituto Tecnológico de Durango. UPIDET. Felipe Pescador 1830 Ote. 34080 Durango, Dgo., México

2 Departamento de Investigación y Posgrado en Alimentos. Facultad de Química. Universidad Autónoma de Querétaro. C.U., Cerro de la Campanas S/N 76010 Querétaro, Qro., México.
\end{abstract}

\section{ABSTRACT}

Coffee is one of the most popular and demanded drinks throughout the world; its consumption goes from the ceremonial to the casual, therefore, the plantations destined for its production are valuable. Besides, the coffee tree is perennial, which guarantees leaves supply throughout the year. Additionally to flowers, coffee leaves have been little studied and commercialized, although they represent an important source of phytochemicals. In flowers, different volatile compounds have been detected; while in leaves, bioactive compounds such as chlorogenic acid and mangiferin have been reported as major phenolics. Both compounds are recognized with anti-inflammatory, antioxidant, anti-obesity and anti-carcinogenic effects. These phytochemicals are produced by the plant as a defense mechanism against biotic or abiotic stresses such as pathogens or adverse weather conditions. This review describes the non-conventional applications that aerial parts of the coffee tree could have as therapeutic or agronomic agents, in addition to the uses that have traditionally been linked to the Coffea plant.

Keywords: coffee leaves, mangiferin, chlorogenic acid, phenolics, diterpenes

\section{RESUMEN}

El café es una de las bebidas más populares y demandadas en todo el mundo, su consumo va desde lo ceremonial a lo casual, por lo tanto, las plantaciones destinadas a su producción son valiosas. Además, el cafeto es perenne, lo que garantiza el suministro de hojas durante todo el año. Adicionalmente a las flores, las hojas de café han sido poco estudiadas y comercializadas, aunque representan una fuente importante de fitoquímicos. En flores, se han detectado diferentes compuestos volátiles; mientras que en las hojas, los compuestos bioactivos como el ácido clorogénico y la mangiferina han sido reportados como los principales compuestos fenólicos. Ambos compuestos son reconocidos con efectos anti-inflamatorios, antioxidantes, antiobesogénicos y anticancerígenos. Estos fitoquímicos son producidos por la planta como un mecanismo de defensa contra el estrés biótico o abiótico, como pueden ser los patógenos o condiciones climáticas adversas. Este artículo de revisión describe las aplicaciones no convencionales que podrían tener las partes aéreas del cafeto como agentes terapéuticos o agronómicos, además de los usos que tradicionalmente se han vinculado a la planta de café.

Palabras clave: hojas de cafeto, mangiferina, ácido clorogénico, fenólicos, diterpenos

\section{INTRODUCTION}

Coffee is one of the world's most popular beverages that has grown steadily in commercial importance during the last 150 years (Daglia et al., 2000). Coffee occupies the second place after petrol on the international market. Some authors have reported more than 120 species of Coffea. However, Coffea canephora and Coffea arabica are the most cultivated varieties worldwide, and the latter supplies more than $70 \%$ of the coffee distributed internationally (Davis et al., 2011; Patay et al., 2016a; 2016b); in these species lays the importance of the cultivation of coffee trees.

Coffea arabica and Aloe vera are amongst the most valuable of all natural products on international markets (Van Wyk, 2015). The global coffee industry is worth over US\$50 billion, with key players being over 25 million farmers tending over 3 billion coffee trees (Nair, 2010). Most of these farmers are mainly reliant on coffee as a legal source of income for their livelihoods. Global annual coffee consumption exceeds 7 million tons from over 2 billion coffee cups brewed daily, making coffee one of the most traded agricultural export commodities from developing countries in sub-Saharan Africa, Asia, and Central America (Chemura et al., 2017).

Despite the successful story and positive forecasts of the coffee grain agribusiness, very little has been done and published on the value and utilization of coffee tree aerial parts. Coffee flowers and residual leaves from the tree trimmings represent an important source of phytochemicals that has been partially explored. This raw material might be a potential source of bioactive chemical compounds with impact in the same agricultural field or for providing novel human health nutraceuticals (Figure 1). 


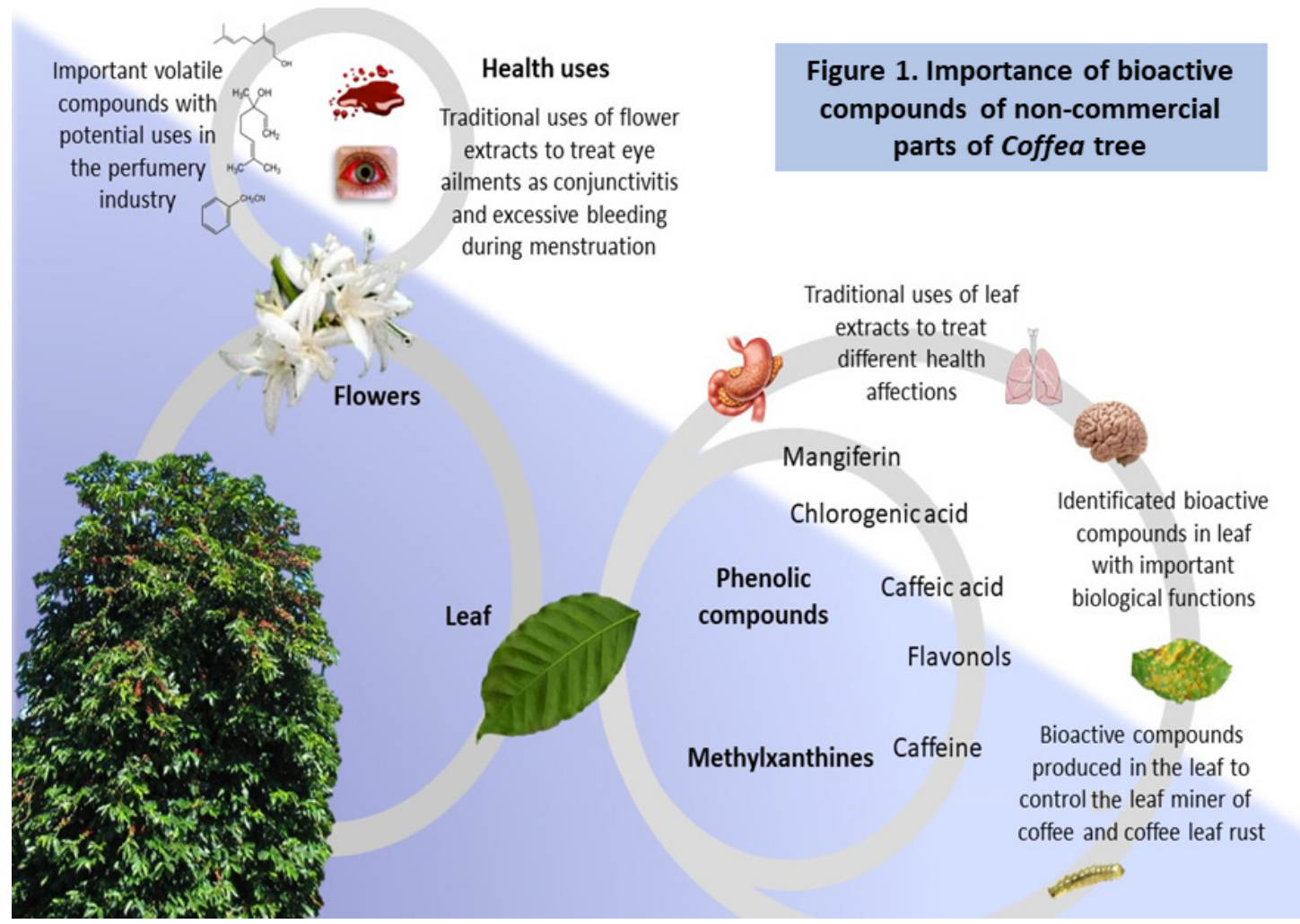

Figure 1. Importance of bioactive compounds of non-commercial pats of Coffea tree.

Figura 1. Importancia de los compuestos bioactivos de las partes no comerciales de Coffea tree.

\section{METHODOLOGY}

An information search was carried out following the key words Coffea and coffee leaves, Coffea flowers, characterization of Coffea, importance of Coffea, traditional uses of Coffea, chlorogenic acid, mangiferin, therapeutically uses from Coffea, in different databases as Scopus, Web of Science and EBSCOhost, and web search engines as Google Scholar. More than 250 significant titles were obtained in the search, which were analyzed and considered for discussion in this publication. The resulting state-of-the-art on the use of aerial parts of the Coffea tree is introduced.

\section{Beginning of the uses of Coffea}

Green coffee beans that are roasted, ground, and brewed to produce the popular beverage known all over the world are actually the seeds contained in fruits from trees and shrubs naturally grown in the shade of the African forests, but also in the Madagascar and Mauritius islands. It is also cultivated in other tropical areas such as equatorial Afri$\mathrm{ca}$, Java, Sumatra, some islands of the Dutch East Indies, West Indies, India, Arabia, the islands of the Pacific, Mexico, and Central and South America (Ukers 1935; Davis et al., 2007).

Coffea species are generally found in the equatorial region, ranging from 200 to $1200 \mathrm{~m}$ in tropical or subtropical zones with temperatures of 18 to $22^{\circ} \mathrm{C}$. However, the identified optimum altitude for wild Coffea species is between 1300 to $1600 \mathrm{~m}$ (Tesfaye et al., 2014).

\section{Coffea flowers}

Flowering is the key reproductive phase of Coffea plants and from its magnitude depends most of the resulting harvesting (Camayo et al., 2003). Flowers of many plant species emit floral scent to attract, for defense and protection against abiotic stress and herbivores. Such scents are often complex mixtures of various small aliphatic molecules, mostly terpenoid, phenylpropanoid, and benzenoid compounds emitted by flowers into the atmosphere. The relative abundances and interactions between these compounds give the flower its unique, characteristic fragrance. In nature, structure, color, and scent are critical factors in attracting pollinators to flowers (Dudareva \& Pichersky, 2006). Knowledge of the chemistry of floral scents is critical in understanding their evolution and biological functions. The study of the chemical composition of the mixtures emitted by flowers is also of commercial importance in the perfumery and flavor industries (Stashenko et al., 2013).

The first investigation of the chemical composition of the flower of Coffea arabica was carried out by Emura et al. in 1997. The volatile composition was evaluated in hexane extracts of coffee flowers (Coffea arabica L.) analyzed by GC-MS and found to comprise a significant number of nitrogen-containing aromatic compounds as well as phenylethane derivatives. In addition to monoterpenoids such as geraniol (16.5\% relative peak area, RPA), linalool (14.3\% RPA) and nerol (10.5\% RPA), N-containing aromatic compounds (e.g., phenyl acetonitrile, $32 \% \mathrm{RPA}$ ) and phenylethane derivatives were found in 
these extracts analyzed by GC-MS. For example, 2,3-epoxygeraniol and 6,7-epoxygeraniol occurred in low amounts and their optical purity was determined (Emura et al., 1997). More recently, around 150 different chemical substances were isolated by headspace, distillative, solvent and supercritical fluid extractive techniques from Coffea arabica flowers (Stashenko et al., 2013). Hydrocarbons (mostly, $C_{13}-C_{30} n$-paraffins) were the predominant class in all of the sorptive extraction fractions (e.g., HS-SPME, MW-HS-SPME, distillates), followed by terpenoids or oxygenated compounds (depending on the isolation technique).

As part of flower conformation, colleters are secretory structures present in different organs of members in more than 60 angiosperm families, including Rubiaceae, Loganiaceae and Apocynaceae. The colleters in the stipules of Coffea arabica are classified as 'standard type'. This type of colleter is formed by a secretory epidermis and the central axis of parenchyma cells, without vascular tissue. The origin of this type of colleter involves the protoderm and the ground meristem, as described for the colleters of Caryocar brasiliense Camb. (Lersten, 1974a; 1974b; Thomas \& Dave, 1989; de Castro Miguel et al., 2006; Paiva \& Machado, 2006).

During development, a viscous exudate of unknown composition covers coffee buds/flowers. The functional role of this secretion has never been proved, but it is argued that it protects the dormant coffee floral bud from dehydration during dry season, as has been suggested for many other plant species. Some investigations found evidence for a functional role of colleters and their exudate in the floration and seed quality (Mayer et al., 2013).

In addition to the volatiles composition in coffee flowers, there are reports of the traditional use of Coffea flowers to treat disease conditions. Coffea benghalensis flowers are used to treat the excessive bleeding during menstruation in some regions of Nepal (Ghimire \& Bastakoti, 2009), and during childbirth, as well as to treat conjunctivitis in West Bengal, India (Bose et al., 2015). Coffea fragrans flowers are used to treat eye ailments too in the district of Assam, India (Das and Bordoloi, 2016).

\section{Coffea leaves}

Coffea spp. is a perennial plant and evergreen in nature (Murthy \& Manonmani, 2008). The coffee tree belongs to the subkingdom of Angiosperms plants, which includes all plants that reproduce by seeds enclosed in a box-like compartment, known as the ovary, at the base of the flower. The Coffea genus belongs to the botanical family Rubiaceae, which has some 500 genera and over 6000 species. Other members of the family include gardenias. Coffee trees are part of the Coffea genus, which is by far the most economically important member of the Rubiaceae family (Ukers, 1935).

Originally, coffee may have been a kind of wine made from the coffee fruit. In coffee countries even today, the natives are very fond and eat it freely of the ripe coffee cherries, voiding the seeds. The pulp surrounding the coffee seeds (beans) is pleasant to taste, has a sweetish, aromatic flavor and quickly ferment when allowed to stand (Ukers, 1935). Coffea arabica is one of the more frequently reported medicinal plant (Woldeab et al., 2018). However, the use of coffee goes beyond the ultimate use of the grain, and in the present review refers to the use of other parts of the Coffea tree, such as leaves and flowers, used for the benefit of human health, in a traditional way and supported by scientific evaluations.

\section{Traditional uses of Coffea leaves}

Coffea leaves, taken as decoction or infusions, are consumed to treat some affections or health problems as part of the tradition of many people around the world; some common conditions are stomach discomfort, body pain, fever, respiratory problems, etc. (Table 1). However, the acceptability of the drink was not simple, in the 1950's, the distribution of Coffea arabica infusions in London markets was not sensorially acceptable by consumers because of its taste (Cramer, 1957). Currently, in the interest and acceptability of functional foods and beverages, these products have become a large market worldwide (Corbo et al., 2014).

Table 1. Traditional uses of Coffea leaves around the world.

Tabla 1. Usos tradicionales de las hojas de cafeto en todo el mundo.

\begin{tabular}{|c|c|c|}
\hline $\begin{array}{l}\text { Coffea } \\
\text { species }\end{array}$ & Use & Reference \\
\hline C. arabica & $\begin{array}{l}\text { Topical use of infusion to } \\
\text { stop hair loss in Eastern } \\
\text { regions of Cuba }\end{array}$ & Heredia et al. (2018) \\
\hline Coffea spp. & $\begin{array}{l}\text { Leaves used in the } \\
\text { treatment of TB related } \\
\text { diseases or their symptoms }\end{array}$ & Sharifi-Rad et al. (2017) \\
\hline C. liberica & $\begin{array}{c}\text { Tea leaves used as a laxative } \\
\text { drug }\end{array}$ & $\begin{array}{l}\text { Belayneh and Bussa } \\
\text { (2014) }\end{array}$ \\
\hline C. arabica & $\begin{array}{l}\text { The leaf sap to treat diarr- } \\
\text { hea and intestinal pain in } \\
\text { Africa }\end{array}$ & $\begin{array}{l}\text { Lamorde et al. (2010) } \\
\text { Belayneh and Bussa } \\
\text { (2014) }\end{array}$ \\
\hline C. arabica & $\begin{array}{l}\text { Leaves used to manage } \\
\text { HIV/AIDS in some districts } \\
\text { of Uganda }\end{array}$ & Lamorde et al. (2010) \\
\hline C. arabica & $\begin{array}{l}\text { Leaves both orally or locally } \\
\text { to treat migraine in Cuba }\end{array}$ & \multirow{7}{*}{ Ross (2007) } \\
\hline C. arabica & $\begin{array}{l}\text { Fresh leaves or infusion } \\
\text { onto painful body parts in } \\
\text { Cuba }\end{array}$ & \\
\hline C. arabica & $\begin{array}{l}\text { Decoction coffee leaves } \\
\text { for headache and stomach } \\
\text { pains in Nicaragua }\end{array}$ & \\
\hline C. arabica & $\begin{array}{l}\text { Infusion as cough suppres- } \\
\text { sant in Peru }\end{array}$ & \\
\hline C. arabica & $\begin{array}{l}\text { Infusion to treat fever in } \\
\text { Mexico }\end{array}$ & \\
\hline C. arabica & $\begin{array}{l}\text { Stimulation of prolactin's } \\
\text { production in Mexico }\end{array}$ & \\
\hline C. canephora & $\begin{array}{c}\text { Tea leaves used for bleeding } \\
\text { accompanying abortion in } \\
\text { Africa }\end{array}$ & \\
\hline
\end{tabular}




\section{Phytochemicals compounds reported in Coffea leaves}

The therapeutic properties reported for Coffea leaves are directly related to their phytochemical composition. Some compounds have already been reported in Coffea leaves, such as lipids (Delaroza et al., 2014), alkaloids (Zheng and Ashihara, 2004), carbohydrates (Brum et al., 2013; de Lima et al., 2014), some phenolic compounds as caffeic, chlorogenic, p-coumaric, ferulic and sinapic acids, as well as flavonoids including rutin, quercetin, kaempferol and isoquercitrin (Patay et al., 2016c). Dicaffeoylquinic acids, 5-CQA, and feruloylquinic acids have also been detected in the leaves of $C$. canephora (Mondolot et al., 2006) (Figure 2).

Researchers have observed the influence of solar radiation on the composition of leaves (Sanchez et al., 2018), particularly in their phenolic composition, observing cis isomers and higher concentration of chlorogenic acid in leaves exposed directly to the sun with respect to leaves in the shade (Clifford et al., 2008; Delaroza et al., 2014). The presence of compounds such as anthocyanins in Coffea arabica var. Purpurascens, prevents degradation of isomers of chlorogenic acid exposed to UV radiation (Domingues Júnior et al., 2012). The hydroxycinnamic acids content in $C$. arabica is higher than in other species such as Coffea sessilifl Bridson, Coffea resinora Hook. f., Coffea leroyi A.P. Davis, and the presence of xanthones as mangiferin has been identified in higher concentration in young leaves (Talamond et al.,
2008; Campa et al., 2012). The increase in temperature also affects the leaves carbohydrate composition, observing concentration variations of arabinose, galactose and xylose under heating stress conditions (Lima et al., 2013).

The age of leaves is an important factor for their phytochemical composition (Leitão et al., 2011). Concentrations of caffeine and some phenolics like flavanols (i.e., catechin, epicatechin gallate, catechin gallate and epicatechin) are higher in young leaves respect to mature ones, presenting a caffeine content of 1.8-3.2 mg/g (Ratanamarno \& Surbkar, 2017). The mineral composition, specifically the sodium to potassium ratio, also affects the leaves caffeine concentration (Clemente et al., 2015). Total phenolic content is higher in young leaves $(174 \mathrm{mg} / \mathrm{g})$ than mature ones $(138.9 \mathrm{mg} / \mathrm{g})$. The development of fruits in the plant represents another factor of variation for leaves composition; those plants with fruits have lower phenolic content in leaves respect to plants without formation of fruits (Salgado et al., 2008). Additionally, processing method, age of leaves and time of extraction, may selectively condition the phytochemical and phenolic contents. Consequently, the particular antioxidant and antiinflammatory responses of the coffee leaves would determine their potential as a suitable source for novel natural health products (Chen et al., 2018).

Phenolic compounds in coffee leaves provides important biological functions; among them chlorogenic acid
1)<smiles>O=C(/C=C/c1ccc(O)c(O)c1)OC1CC(O)(C(=O)O)CC(O)C1O</smiles>

2)<smiles>O=c1c2cc(O)c(O)cc2oc2cc(O)c(O)c(O)c12</smiles>

3)<smiles>O=C(O)/C=C/c1ccc(O)c(O)c1</smiles>

4)<smiles>COc1cc(/C=C/C(=O)O)cc(OC)c1O</smiles>

5)<smiles>Cn1c(=O)c2c(ncn2C)n(C)c1=O</smiles>

9)<smiles>Oc1cc(O)c2c(c1)O[C@H](c1ccc(O)c(O)c1)C(O)C2</smiles>

6)<smiles>CC12CC[C@H](CO)[C@@](O)(CC[C@H]1CCO)CC2</smiles>

7)<smiles>CC12CCC(CO)[C@H](O)CC1CCC1c3ccoc3C=CC12</smiles>

8)

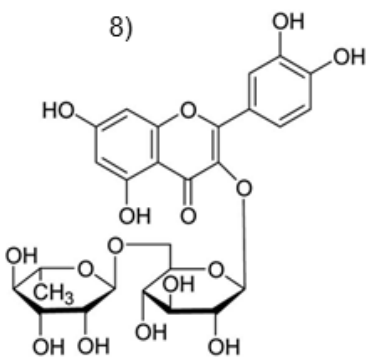<smiles>O=C(OC1Cc2c(O)cc(O)cc2OC1c1ccc(O)c(O)c1)c1cc(O)c(O)c(O)c1</smiles><smiles></smiles><smiles>O=C(/C=C/c1ccc(O)c(O)c1)OC1C(=O)OC2(C(=O)O)CC(O)C1C(=O)O2</smiles>

Figure 2. Major phytochemicals associated with aerial parts of Coffea species. 1) chlorogenic acid, 2) mangiferin, 3) caffeic acid, 4) sinapic acid, 5) cafein, 6) cafestol, 7) kawheol, 8) rutin, 9) catechin, 10) epicatechin gallate, 11) quercetin, 12) 1,5-dicaffeoylquinic acid. Figura 2. Fitoquímicos mayoritarios asociados con las partes aéreas de especies de Coffea. 1) ácido clorogénico, 2) mangiferina, 3) ácido cafeico, 4) ácido sináptico, 5) cafeína, 6) cafestol, 7)kawheol, 8) rutina, 9) catequina, 10) galato de epicatequina, 11) quercetina, 12) ácido 1,5-dicafeoilquínico. 
exhibits anti-diabetic and anti-lipidemic properties through regulation of the activation pathway of the cellular energy homeostasis enzyme AMPK (Ong et al., 2013). It is an important anti-inflammatory agent able to inhibit the nuclear translocation of $\mathrm{NF}-\mathrm{\kappa} \beta$ and attenuate proinflammatory cytokines such as interleukins $1 \beta, 6$ and tumor necrosis factor TNFa (Hwang et al., 2014). It also improves liver steatosis, insulin sensitivity and reduces chronic inflammation in obese mice (Ma et al., 2015). Likewise, chlorogenic acid increases antioxidant capacity in liver through the transcription factor Nrf2 signaling pathway (Shi et al., 2016), and exerts an anti-carcinogenic effect that has been reported in different models (Deka et al., 2017; Yan et al., 2017; Sadeghi Ekbatan et al., 2018; Yamagata et al., 2018).

On the other hand, some substances found in coffee leaves could be prejudicial to human health; particularly, cafestol (CAF) and kahweol (KAH) are two anti-nutritional diterpenes unique to coffee. These biologically significant diterpenoids are associated with lipids of coffee and are reported to be responsible for the hypercholesterolemic effects in humans (Sridevi \& Giridhar, 2016). Diterpenes $\mathrm{CAF}$ and $\mathrm{KAH}$ are the major unsaponifiable lipid fraction components in green and roasted coffee beans (Kitzberger et al., 2013; dos Santos Scholz et al., 2016). They also affect beverage quality (Del Terra et al., 2013). In addition, they are commonly associated with anti-inflammatory, anticarcinogenic and antioxidant properties in human health (Chu et al., 2011). In industry, they are used in pharmaceuticals, cosmetic products (e.g., oils and sunscreens) and soluble coffee flavorings. CAF also relates to volatile phenolic compounds released by flowers, which could be responsible for attracting pollinators (Del Terra et al., 2013). However, CAF is also associated with increased cholesterol levels in blood plasma (i.e., hyperlipidemia) at higher ingestion doses, depending on the filter process method used to prepare the coffee drink (Naidoo et al., 2011).

Three diterpenes (i.e., CAF, KAH and 16-O-methylcafestol), which are common ingredients in coffee beans, were also identified in Coffea trees leaves. CAF, only traces of $\mathrm{KAH}$ and additionally 16-O-methylcafestol were found in leaves of four Arabica varieties (Kölling-Speer \& Speer, 1997). Recently, the CAF and KAH profiles were determined by HPLC in leaves, roots, flowers buds, flowers and fruits (i.e., perisperm and endosperm). The identification and quantification of CAF and $\mathrm{KAH}$ was possible in roots, flowers buds and flowers, but in the case of $C$. arabica leaves, these diterpenes were not detected particularly in that investigation (Ivamoto et al., 2017).

\section{Novel identification of mangiferin in Coffea leaves}

Mangiferin (2-C- $\beta$-D-glucopyranosyl-1,3,6,7-tetrahydroxyxanthone) is a phenolic compound derived from bark and leaves of the Anacardiaceae and Gentianaceae families, which may be a unique and underutilized source of potentially therapeutic agents (Yoshimi et al., 2001). Mangiferin has been reported in at least 34 vegetal species (Vyas et al., 2012), including leaves of Coffea spp. (Figure 2).
The histochemical observations for the detection of mangiferin in leaves and fruits have been possible on three species: C. pseudozanguebariae, C. arabica and C. canephora, identifying a preferential localization of mangiferin in palisade and spongy (mesophyll) parenchyma of $C$. pseudozanguebariae leaves (Conéjéro et al., 2014). In comparison, the same transverse sections of leaves indicated that mangiferin is absent in C. canephora, but present at low concentration in $C$. arabica. In C. pseudozanguebariae, C. eugenioides and C. arabica, mangiferin was present at each development stage, but not detected in C. canephora in any case. Irrespective of the developmental stage, the highest mangiferin content was observed in leaves of $C$. eugenioides (Campa et al., 2012). This report is the first in identifying the presence of mangiferin in varieties of $C$. arabica, but others researchers have identified this xanthone in different varieties of Coffea.

The concentration of mangiferin and its isomer were quantitated in leaves of five coffee trees species from Brazil and Costa Rica, showing in Coffea species a higher concentration of this compound (0.67-4.97 g/kg) (Trevisan et al., 2016). The authors have concluded that consumption of tea brews made of coffee leaves as a natural source of mangiferins, may contribute significantly to a prophylactic intake of these potentially health-promoting phenolic compounds. Mangiferin was initially isolated from leaves, bark, and peel of mango (Mangifera indica L.), a well-known plant for its numerous pharmacological properties such as anti-inflammatory, antidiabetic, antihyperlipidemic, and neuroprotective activities, as well as antioxidant and antimicrobial effects in biotic stress conditions (Campa et al., 2012). The anti-inflammatory properties of mangiferin can be attributed, among other mechanisms, to the inhibitory effect on TNFa, as demonstrated in a hyperalgesia model (Rocha et al., 2018), inhibiting NF-K $\beta$ activity (Jang et al., 2016).

It was discovered that mangiferin improves cisplatin-induced nephrotoxicity in vitro and in vivo by attenuating oxidative stress induction and upregulating transcription factors such as Nrf-2, which mediates pro-survival signaling cascades through PI3K activation (Sadhukhan et al., 2018). The promotion in the expression of the intracellular signaling pathway PI3K was also observed in an oxidative stress model in normal cells of kidney epithelium induced by ter-butyl hydroperoxide (tBHP), where mangiferin has shown the potential to maintain normal cellular homeostasis. Thus, mangiferin is situated as a possible candidate for the oxidative stress treatment associated to renal complications thanks to its antioxidant and anti-inflammatory properties (Saha et al., 2016). Other studies have revealed that mangiferin could prevent the secretion of interleukins 6 and 8 (IL-6 and IL-8) induced by cadmium by the endothelial cells of the human glomerulus, modulating the NF- $\mathrm{k} \beta$ and phospho-JNK phospho-p38 signaling pathways, so that mangiferin could be used to prevent kidney inflammation (Rajendran et al., 2015).

This xanthone is also attributed with neuroprotection properties. Its activity has been evaluated in combination with morin, demonstrating a strong protection against 
$A \beta$-induced mitochondrial dysfunction and neuronal cell death (Alberdi et al., 2018). Therefore, they are promising therapeutic tools for restoring mitochondrial functions and redox homeostasis in Alzheimer's disease. The use of mangiferin in an in vivo model demonstrated its anti-inflammatory and anti-arthritic capacity as an inhibitor of NF-к $\beta$ and considerably lower levels of the cytokine IL-10, possibly due to the inhibition of the cyclooxygenase-2 (COX-2) enzyme (Pal et al., 2018). Previous works have reported that the mangiferin also impedes COX-2 expression by upregulating TGF- $\beta$ (García-Rivera et al., 2011; Mahmoud-Awny et al., 2015: Bulugonda et al., 2017). In addition, it has been reported the capacity of mangiferin for inhibiting IL-1 $\beta$-induced inflammatory response in human osteoarthritis chondrocytes by activating the type II nuclear receptor PPAR- $\gamma$ (Qu et al., 2017).

It has been suggested that mangiferin could be used for diabetic cardiomyopathy treatment, since it can prevent the release of inflammatory cytokines, inhibit ROS accumulation, avoid production of advanced glycation end products (AGE) and their receptors (RAGE), and promote translocation of NF-KB (Hou et al., 2015). Evidence suggests that mangiferin could be a useful and economical compound not only to maintain and improve health, but also to significantly improve prospects in certain cancers by reducing the likelihood of developing them. It controls the inflammation process by modulating the expression of NF-k $\beta$ and PPARY, thereby regulating the expression of COX-2, Intercellular Adhesion Molecule-1 (ICAM-1), B Cell Lymphoma-2 (bcl-2), IL-6, IL-8, C-X-C Chemokine Receptor type-4 (CXCR4), X linked Inhibitor of Apoptosis Protein (XIAP) and the Vascular Endothelial Growth Factor (VEGF) (Gold-Smith et al., 2016). An anticancer effect of mangiferin has been reported in breast, lung, prostate, gastric, colon and blood cancers (Table 2). Antiobesity effects of mangiferin extracts, capable of regulating blood glucose and lipid levels, have also been reported (Ramírez et al., 2017). A consequent result was also the decrease in body weight gain in an in vivo model subjected to a high-calorie diet.

\section{Phytochemicals as defense against leaves pests in Coffea}

Besides their therapeutic properties, secondary metabolites in Coffea leaves also represent a rich source of bioactive principles that play an important role as plant defense mechanisms to deal with biotic and abiotic factors. Varied microorganisms and pests have been reported to attack the coffee tree with diverse results, sometimes with huge agronomic and economic impacts. As an example, since it was reported in 1867, Hemileia vastatrix Berkeley and Broome, a fungus that causes coffee leaf rust, has caused serious affectations to plantations of Coffea arabica L. The devastating effects got to the point of eradicating this species from some regions (Várzea \& Marques, 2005), including Central and South America, where the plantations loss represented millions of dollars (Avelino et al., 2015).

The ability of the plant to discriminate between its own molecules and those of harmful organisms represents the first essential line of defense of any immune system. Therefore, plants respond to the infection of pathogens using a multilayer immune system (Doehlemann \& Hemetsberger, 2013). Particularly, it has been reported the link between phenolic compounds, polysaccharides and cell wall proteins of the plant with the improvement of its protection mechanisms to the digestion by microbial degrading enzymes; therefore, increasing global resistance to the fungi (Bily et al., 2003).

Among the phenolic compounds associated with coffee resistance to $H$. vastatrix, are chlorogenic acids bound to lignin (Silva et al., 2006; Leitão et al., 2011). The benefit of eliciting (i.e., chemical treatment) Coffea plants with silicon has been studied to increase the concentration of chlorogenic acid and therefore enhancing their resistance to the fungus; however, no influence of silicon has been found in the expected response (Rodrigues et al., 2011). The content of other phenolics such as proanthocyanidins could be associated with rust resuscitation when higher concentrations of these compounds are observed in C. canephora leaves, a rust-resistant species, with respect to the leaves of $C$. arabica, a susceptible species (de Colmenares et al., 1998).

The pesticidal effect of some phytochemical compounds such as methylxanthines, particularly caffeine and phenolic compounds such as chlorogenic acids, has been studied to treat Leucoptera coffeella (Lepidoptera: Lyonetiidae) (Magalhaes et al., 2008). It is commonly called the leaf miner of coffee, considered one of the most serious coffee pests in the neotropical regions (Green, 1984). The damage it causes is considerable since its populations reaches the level of plague, when defoliation can be as higher as two thirds of the tree biomass; therefore, production losses can be up to one half of the normal rates (Vega et al., 2006). In this case, the damage to the plant is typically caused by the larva, when piercing the upper part of the leaf epidermis.

Some commercial coffee genotypes (e.g., Coffea canephora L. and Coffea racemosa Lour. and its hybrids with Coffea arabica L.) exhibit high pesticidal activity (i.e., 100\% mortality) toward Leucoptera coffeella, indicating their antibiosis resistance. The presence of $L$. coffeella correlates actually with a decrease in the foliar content of phenolic acids such as chlorogenic acid, which makes the leaves also vulnerable to other infestations (Magalhães et al., 2010).

\section{CONCLUSIONS}

The coffee tree flowers and leaves have been little studied and exploited as byproducts and significant parts of the Coffea species. However, their phytochemical composition makes them attractive alternatives for use as source of bioactive nutraceuticals or pesticidal agents. Particularly, leaves contain phenolic compounds such as chlorogenic acid and mangiferin, which have been reported with diverse therapeutic and biological properties. The information gathered in this compilation highlights the potential resource represented by the aerial parts of the Coffea plant, in addition to the coffee grain, for their future investigation and industrial utilization. 
Table 2. Studies that evaluated the mangiferin anti-cancer property in different models.

Tabla 2. Estudios que evaluaron la propiedad anticancerígena de la mangiferina en diferentes modelos.

\begin{tabular}{lll}
\hline Model & Observations & Reference \\
\hline
\end{tabular}

Androgen receptor positive LnCap

The human leukemia Molt-4 cells

Estrogen-independent MDA-MB-231

breast cancer cells

Colorectal SW-480 adenocarcinoma cells

Different cell lines showed cell growth suppression in a dosedependent manner when treated with extracts of the mango

Noratto et al., 2010

Human lung A-549 carcinoma cells varieties Ataulfo and Haden rich in mangiferin.

\begin{tabular}{|c|c|c|}
\hline Gastric carcinoma cells SGC-7901 and BCG-823 & $\begin{array}{l}\text { Mangiferin inhibited the proliferation in dose- and time-dependent } \\
\text { manners, inhibiting cell growth and inducing apoptosis of gastric } \\
\text { cancer cells through inhibition of the PI3K/Akt pathways with } \\
\text { relative safety. }\end{array}$ & Du et al., 2018 \\
\hline Human prostate cancer cells PC3 & $\begin{array}{l}\text { Mangiferin inhibited proliferation and induced apoptosis in } \\
\text { PC3 human prostate cancer cells; this effect was correlated with } \\
\text { downregulation of } \mathrm{BCl}-2 \text { and upregulation of miR-182. }\end{array}$ & Li et al., 2016 \\
\hline
\end{tabular}

Breast cancer and colorectal carcinoma MCF-7 Therapeutic in vitro anticancer effect of nanoparticles of mango leaf and HCT-116 cells extracts, rich in mangiferin, were observed in cytotoxicity tests.

Anoop et al., 2018

Antiproliferative and preventive capacity of an aqueous extract of

Human colon adenocarcinoma cell line SW480

Rodent model of colorectal cancer
Mangifera indica cv. Azúcar was observed on cells SW480 and in a rodent model.
Corrales-Bernal et al., 2014

Chieli et al., 2009

Function inhibition of the MDR-1/P-glycoprotein (P-gp ABCB1)

Caco-2 cell sub-line selected by resistance to multidrug transporter, leading to potential herb-drug interactions vincristine (Caco-2/VCR) with P-gp activity.

Mangiferin delays breast malignancy development and progression by inhibiting different signaling pathways required in mitogenic

signaling and metastatic progression.

Deng et al., 2018

Breast cancer Rac1/WAVE2 signalling

Mango leaf extracts showed protective properties against oxidation and cytotoxic effects in breast cancer cell lines, causing minor damage to non-carcinogenic cells, maybe due to synergy of

Fernández-Ponce et al., 2017

Breast cancer cells MCF7 and MDA-MB-231

Non-tumorigenic cells MCF10

mangiferin and other phenolic compounds in extracts.

Non polar extract (chloroform extract) of fruit peels exhibited

Breast cancer cells MCF-7

capacity to mediate apoptosis via oxidative stress mechanism, which appeared to be due to bio-active phytochemicals such as mangiferin.

Ediriweera et al., 2017

Mangiferin has selectively blocked breast cancer cell growth by inducing apoptosis and arresting cell proliferation through combined action on cholesterol and proteasome pathways, as well

Cuccioloni et al., 2016 inhibiting plasmin-mediated mechanisms of cell migration.

Mangiferin inhibits the activation of $\beta$-catenin pathway in breast cancer cells, showing clear antitumor effect.

Li et al., 2013

Mangiferin as a novel Nrf2 activator reduces oxidative stress and protects normal cells without reducing the sensitivity to etoposide of HL-60 leukemia cells in vitro. Mangiferin may be a potential chemotherapy adjuvant.

Zhang et al., 2014 Human HL-60 myeloid leukemia cells and
mononuclear human umbilical cord blood cells (MNCs)

Mangiferin could inhibit telomerase activity of $\mathrm{K} 562$ cells in time-

Leukemic cells lines K562

and concentration-dependent manners that could induce apoptosis and up-regulate the levels of Fas in K562 cells.

Mangiferin induced G2/M phase cell cycle arrest via the cdc2-cyclin B1 pathway, and induced cell apoptosis via the PKC-NF-KB pathway.
Cheng et al., 2007

Shi et al., 2016
Human lung adenocarcinoma cells A549 


\section{ACKNOWLEDGEMENTS}

First author (MCRV) is grateful with the Mexican Council of Science and Technology (CONACyT) for granting graduate scholarship. The technical support and samples collection from M.C. Rosalío López-Morgado from PICIP (café), S.E. Teocelo, INIFAP is fully recognized.

\section{REFERENCES}

Alberdi, E., Sánchez-Gómez, M.V., Ruiz, A., Cavaliere, F., OrtizSanz, C., Quintela-López, T., Capetillo-Zarate, E., SoléDomènech, $S$. and Matute, C. 2018. Mangiferin and morin attenuate oxidative stress, mitochondrial dysfunction, and neurocytotoxicity, induced by amyloid beta oligomers. Oxidative Medicine and Cellular Longevity. vol. 2018, Article ID 2856063, 13 pp.

Anoop, N. V., Jacob, R., Paulson, J.M., Dineshkumar, B. and Narayana, C.R. 2018. Mango leaf extract synthesized silver nanorods exert anticancer activity on breast cancer and colorectal carcinoma cells. Journal of Drug Delivery Science and Technology. 44: 8-12.

Avelino, J., Cristancho, M., Georgiou, S., Imbach, P., Aguilar, L., Bornemann, G., Läderach, P., Anzueto, F., Hruska, A.J. and Morales, C. 2015. The coffee rust crises in Colombia and Central America (2008-2013): impacts, plausible causes and proposed solutions. Food Security. 7(2): 303-321.

Belayneh, A. and Bussa N.F. 2014. Ethnomedicinal plants used to treat human ailments in the prehistoric place of Harla and Dengego valleys, eastern Ethiopia. Journal of Ethnobiology and Ethnomedicine. 10(1): 18.

Bily, A., Reid, L., Taylor, J., Johnston, D., Malouin, C., Burt, A., Bakan, B., Regnault-Roger, C., Pauls K. and Arnason, J. 2003. Dehydrodimers of ferulic acid in maize grain pericarp and aleurone: resistance factors to Fusarium graminearum. Phytopathology. 93(6): 712-719.

Bose, D., Roy, J.G., Mahapatra, S.D., Datta, T., Mahapatra, S.D. and Biswas, H. 2015. Medicinal plants used by tribals in Jalpaiguri district, West Bengal, India. Journal of Medicinal Plants. 3(3): 15-21.

Brum, C.N.F., Melo, E.F., Barquero, L.O.B., Alves, J.D. and Chalfun-Júnior, A. 2013. Modifications in the metabolism of carbohydrates in (Coffea arabica L. cv. siriema) seedlings under drought conditions. Coffee Science, Lavras. 8(2): 140147.

Bulugonda, R.K., Gangappa, D., Beeda, H., Philip, G.H., Rao, D.M. and Faisal, S.M. 2017. Mangiferin from Pueraria tuberosa reduces inflammation via inactivation of NLRP3 inflammasome. Scientific Reports. 7: 42683.

Camayo, G., Chaves, B., Arcila, J. and Jaramillo, A. 2003. Desarrollo floral del cafeto y su relación con las condiciones climáticas de Chinchiná Caldas. Cenicafé. 54(1): 35-49.

Campa, C., Mondolot, L., Rakotondravao, A., Bidel, L.P., Gargadennec, A., Couturon, E., La Fisca, P., Rakotomalala, J.-J., Jay-Allemand, C. and Davis, A.P. 2012. A survey of mangiferin and hydroxycinnamic acid ester accumulation in coffee (Coffea) leaves: biological implications and uses. Annals of Botany. 110(3): 595-613.

Chemura, A., Mutanga, O. and Odindi, J. 2017. Empirical Modeling of Leaf Chlorophyll Content in Coffee (Coffea Arabica) Plantations With Sentinel-2 MSI Data: Effects of Spectral Settings, Spatial Resolution, and Crop Canopy
Cover. IEEE Journal of Selected Topics in Applied Earth Observations and Remote Sensing. 10(12): 5541-5550.

Chen, X-M., Ma, Z., Kitts, D.D. 2018. Effects of processing method and age of leaves on phytochemical profiles and bioactivity of coffee leaves. Food Chemistry. 249: 143-153.

Cheng, P., Peng, Z., Yang, J. and Song, S. 2007. The effect of mangiferin on telomerase activity and apoptosis in leukemic $\mathrm{K} 562$ cells. Zhong yao cai $=$ Zhongyaocai $=$ Journal of Chinese Medicinal Materials. 30(3): 306-309.

Chieli, E., Romiti, N., Rodeiro, I. and Garrido, G. 2009. In vitro effects of Mangifera indica and polyphenols derived on $A B C B 1 / P-g l y c o p r o t e i n ~ a c t i v i t y$. Food and Chemical Toxicology. 47(11): 2703-2710.

Chu, Y.-F., Chen, Y., Black, R.M., Brown, P.H., Lyle, B.J., Liu, R.H. and Ou, B. 2011. Type 2 diabetes-related bioactivities of coffee: assessment of antioxidant activity, NF-KB inhibition, and stimulation of glucose uptake. Food Chemistry. 124(3): 914920.

Clemente, J. M., Martinez, H.E.P., Alves, L.C., Finger, F.L. and Cecon, P.R. 2015. Effects of nitrogen and potassium on the chemical composition of coffee beans and on beverage quality. Acta Scientiarum. Agronomy. 37(3): 297-305.

Clifford, M.N., Kirkpatrick, J., Kuhnert, N., Roozendaal, H. and Salgado, P.R. 2008. LC-MS $n$ analysis of the cis isomers of chlorogenic acids. Food Chemistry. 106(1): 379-385.

Conéjéro, G., Noirot, M., Talamond, P and Verdeil, J.-L. 2014. Spectral analysis combined with advanced linear unmixing allows for histolocalization of phenolics in leaves of coffee trees. Frontiers in Plant Science. 5: 39.

Corbo, M.R., Bevilacqua, A., Petruzzi, L., Casanova, F.P. and Sinigaglia, M. 2014. Functional beverages: the emerging side of functional foods: commercial trends, research, and health implications. Comprehensive Reviews in Food Science and Food Safety. 13(6): 1192-1206.

Corrales-Bernal, A., Urango, L.A., Rojano, B. and Maldonado, M.E. 2014. Efectos in vitro e in vivo de la pulpa de mango (Mangifera indica cv. Azúcar) en la carcinogénesis de colon. Archivos Latinoamericanos de Nutrición. 64(1): 16-23.

Cramer, P.J.S. 1957. A review of literature of coffee research in Indonesia, SIC Editorial, Inter-American Institute of Agricultural Sciences. Turrialba, Costa Rica. $262 \mathrm{Pp}$.

Cuccioloni, M., Bonfili, L., Mozzicafreddo, M., Cecarini, Scuri, V., Cocchioni, M., Nabissi, M., Santoni, G., Eleuteri, A. and Angeletti, M. 2016. Mangiferin blocks proliferation and induces apoptosis of breast cancer cells via suppression of the mevalonate pathway and by proteasome inhibition. Food \& Function. 7(10): 4299-4309.

Daglia, M., Papetti, A., Gregotti, C., Bertè, F. and Gazzani, G. 2000. In vitro antioxidant and ex vivo protective activities of green and roasted coffee. Journal of Agricultural and Food Chemistry. 48(5): 1449-1454.

Das, A. and Bordoloi, R. 2016. Ethno medical importance of some plants used for the treatment of cattle diseases by the Tiwa tribe of Morigaon district of Assam, India. World Journal of Pharmacy and Pharmaceutical Sciences. 5(5): 1356-1365.

Davis, A.P., Chester, M., Maurin, O. and Fay, M.F. 2007. Searching for the relatives of Coffea (Rubiaceae, Ixoroideae): the circumscription and phylogeny of Coffeeae based on plastid sequence data and morphology. American Journal of Botany. 94(3): 313-329. 
Davis, A.P., Tosh, J., Ruch, N. and Fay, M.F. 2011. Growing coffee: Psilanthus (Rubiaceae) subsumed on the basis of molecular and morphological data; implications for the size, morphology, distribution and evolutionary history of Coffea. Botanical Journal of the Linnean Society. 167(4): 357-377.

Deka, S.J., Gorai, S., Manna, D. and Trivedi, V. 2017. Evidence of PKC binding and translocation to explain the anticancer mechanism of chlorogenic acid in breast cancer cells. Current Molecular Medicine. 17(1): 79-89.

De Castro Miguel, E., Moreira Gomes, V., De Oliveira, M. and Da Cunha, M. 2006. Colleters in Bathysa nicholsonii K. Schum. (Rubiaceae): ultrastructure, secretion protein composition, and antifungal activity. Plant Biology. 8(5): 715-722.

De Colmenares, N.G., Ramírez-Martínez, J.R., Aldana, J.O., RamosNiño, M.E., Clifford, M.N., Pékerar, S. and Méndez, B. 1998. Isolation, characterisation and determination of biological activity of coffee proanthocyanidins. Journal of the Science of Food and Agriculture. 77(3): 368-372.

De Lima, R.B., dos Santos, T.B., Vieira, L.G.E., Ferrarese, M.d.L.L., Ferrarese-Filho, O., Donatti, L., Boeger, M.R.T. and de Oliveira Petkowicz, C.L. 2014. Salt stress alters the cell wall polysaccharides and anatomy of coffee (Coffea arabica L.) leaf cells. Carbohydrate Polymers. 112: 686-694.

Del Terra, L., Lonzarich, V., Asquini, E., Navarini, L., Graziosi, G., Liverani, F.S. and Pallavicini, A. 2013. Functional characterization of three Coffea arabica L. monoterpene synthases: Insights into the enzymatic machinery of coffee aroma. Phytochemistry. 89: 6-14

Delaroza, F., Rakocevic, M., Malta, G.B., Bruns, R.E. and Scarminio, I.S. 2014. Spectroscopic and chromatographic fingerprint analysis of composition variations in Coffea arabica leaves subject to different light conditions and plant phenophases. Journal of the Brazilian Chemical Society. 25(11): 1929-1938.

Deng, Q., Tian, Y.-X. and Liang, J. 2018. Mangiferin inhibits cell migration and invasion through Rac1/WAVE2 signalling in breast cancer. Cytotechnology. 70(2): 593-601.

Doehlemann, G. and Hemetsberger, C. 2013. Apoplastic immunity and its suppression by filamentous plant pathogens. New Phytologist. 198(4): 1001-1016.

Domingues Júnior, A.P., Shimizu, M.M., Magalhães Silva Moura, J.C., Ramos Catharino, R., Augusto Ramos, R., Vasconcelos Ribeiro, R. and Mazzafera, P. 2012. Looking for the physiological role of anthocyanins in the leaves of Coffea arabica. Photochemistry and Photobiology. 88(4): 928-937.

Dos Santos Scholz, M.B., Kitzberger, C.S.G., Pagiatto, N.F., Pereira, L.F.P., Davrieux, F., Pot, D., Charmetant, P. and Leroy, T. 2016. Chemical composition in wild ethiopian Arabica coffee accessions. Euphytica. 209(2): 429-438.

Du, M., Wen, G., Jin, J., Chen, Y., Cao, J. and Xu, A. 2018. Mangiferin prevents the growth of gastric carcinoma by blocking the PI3K-Akt signalling pathway. Anti-cancer Drugs. 29(2): 167175.

Dudareva, N. and Pichersky, E. 2006. Metabolite engineering of floral scent of ornamentals. Journal of Crop Improvement. 18(1-2): 325-346.

Ediriweera, M.K., Tennekoon, K.H., Samarakoon, S.R., Thabrew, I. and De Silva, E.D. 2017. Induction of apoptosis in MCF-7 breast cancer cells by Sri Lankan endemic mango (Mangifera zeylanica) fruit peel through oxidative stress and analysis of its phytochemical constituents. Journal of Food Biochemistry. 41(1): e12294.
Emura, M., Nohara, I., Toyoda, T. and Kanisawa, T. 1997. The volatile constituents of the coffee flower (Coffea arabica L.). Flavour and Fragrance Journal. 12(1): 9-13.

Fernández-Ponce, M., López-Biedma, A., Sánchez-Quesada, C., Casas, L., Mantell, C., Gaforio, J. and de la Ossa, E.M. 2017. Selective antitumoural action of pressurized mango leaf extracts against minimally and highly invasive breast cancer. Food \& Function. 8(10): 3610-3620.

García-Rivera, D., Delgado, R., Bougarne, N., Haegeman, G. and Berghe, W.V. 2011. Gallic acid indanone and mangiferin xanthone are strong determinants of immunosuppressive anti-tumour effects of Mangifera indica L. bark in MDAMB231 breast cancer cells. Cancer Letters. 305(1): 21-31.

Ghimire, K. and Bastakoti, R.R. 2009). Ethnomedicinal knowledge and healthcare practices among the Tharus of Nawalparasi district in central Nepal. Forest Ecology and Management. 257(10): 2066-2072.

Gold-Smith, F., Fernandez, A. and Bishop, K. 2016. Mangiferin and cancer: Mechanisms of action. Nutrients. 8(7): 396.

Green, D.S. 1984. A proposed origin of the coffee leaf-miner, Leucoptera coffeella (Guérin-Méneville)(Lepidoptera: Lyonetiidae)." Bulletin of the ESA. 30(1): 30-31.

Heredia, Y., García, J., López, T., Chil, I., Arias, D., Escalona, J., González, R., Costa, J., Suarez, D. and Sánchez, M. 2018. An ethnobotanical survey of medicinal plants used by inhabitants of Holguín, Eastern Region, Cuba. Boletín Latinoamericano y del Caribe de Plantas Medicinales y Aromáticas. 17(2): 160-196.

Hou, J., Zheng, D., Fung, G., Deng, H., Chen, L., Liang, J., Jiang, Y. and $\mathrm{Hu}, \mathrm{Y}$. 2015. Mangiferin suppressed advanced glycation end products (AGEs) through NF-KB deactivation and displayed anti-inflammatory effects in streptozotocin and high fat diet-diabetic cardiomyopathy rats. Canadian Journal of Physiology and Pharmacology. 94(3): 332-340.

Hwang, S.J., Kim, Y.-W., Park, Y., Lee, H.-J. and Kim, K.-W. 2014. Anti-inflammatory effects of chlorogenic acid in lipopolysaccharide-stimulated RAW 264.7 cells. Inflammation Research. 63(1): 81-90.

Ivamoto, S.T., Sakuray, L.M., Ferreira, L.P., Kitzberger, C.S., Scholz, M.B., Pot, D., Leroy, T. Vieira, L.G., Domingues, D.S. and Pereira, L.F. 2017. Diterpenes biochemical profile and transcriptional analysis of cytochrome P450s genes in leaves, roots, flowers, and during Coffea arabica L. fruit development. Plant Physiology and Biochemistry. 111: 340-347.

Jang, J.-H., Lee, K.-H., Jung, H.-K., Sim, M.-O., Kim, T.-M., Woo, K.-W., An, B.-K., Cho, J.-H. and Cho, H.-W. 2016. Anti-inflammatory effects of 6ख-O-acetyl mangiferin from Iris rossii Baker via NF-kb signal blocking in lipopolysaccharide-stimulated RAW 264.7 cells. Chemico-Biological Interactions. 257: 54-60.

Kitzberger, C.S.G., dos Santos Scholz, M. B., Pereira, L.F.P., Vieira, L.G.E., Sera, T., Silva, J.B.G.D. and de Toledo Benassi, M. 2013. Diterpenes in green and roasted coffee of Coffea arabica cultivars growing in the same edapho-climatic conditions. Journal of Food Composition and Analysis. 30(1): 52-57.

Kölling-Speer, I. and Speer, K. 1997. Diterpenes in coffee leaves. Colloque Scientifique International Sur le Café. 17: 150-154.

Lamorde, M., Tabuti, J.R., Obua, C., Kukunda-Byobona, C., Lanyero, H., Byakika-Kibwika, P. Bbosa, G.S., Lubega, A.. Ogwal-Okeng, J. and Ryan, M. 2010. Medicinal plants used by traditional medicine practitioners for the treatment of HIV/AIDS and related conditions in Uganda. Journal of Ethnopharmacology. 130(1): 43-53. 
Leitão, S., Guerra-Guimarães, L., Bronze, M., Vilas-Boas, L., Sá, M. and Almeida, M. 2011. Chlorogenic acid content in coffee leaves: possible role in coffee leaf rust resistance. Proceedings of the 24th International Conference on Coffee Science (ASIC2010)(Bali).

Lersten, N.R. (1974a). Colleter morphology in Pavetta, Neorosea and Tricalysia (Rubiaceae) and its relationship to the bacterial leaf nodule symbiosis. Botanical Journal of the Linnean Society. 69(2): 125-136.

Lersten, N.R. (1974b). Morphology and distribution of colleters and crystals in relation to the taxonomy and bacterial leaf nodule symbiosis of Psychotria (Rubiaceae). American Journal of Botany. 61(9): 973-981.

Li, H., Huang, J., Yang, B., Xiang, T., Yin, X., Peng, W., Cheng, W., Wan, J., Luo, F. and Li, H. 2013. Mangiferin exerts antitumor activity in breast cancer cells by regulating matrix metalloproteinases, epithelial to mesenchymal transition, and $\beta$-catenin signaling pathway. Toxicology and Applied Pharmacology. 272(1): 180-190.

Li, M., Ma, H., Yang, L. and Li, P. 2016. Mangiferin inhibition of proliferation and induction of apoptosis in human prostate cancer cells is correlated with downregulation of B-cell lymphoma-2 and upregulation of microRNA-182. Oncology Letters. 11(1): 817-822.

Lima, R. B., dos Santos, T.B., Vieira, L.G.E., Ferrarese, M.d.L.L., Ferrarese-Filho, O., Donatti, L., Boeger, M.R.T. and de Oliveira Petkowicz, C.L. 2013. Heat stress causes alterations in the cell-wall polymers and anatomy of coffee leaves (Coffea arabica L.). Carbohydrate Polymers. 93(1): 135-143.

Ma, Y., Gao, M. and Liu, D. 2015. Chlorogenic acid improves high fat diet-induced hepatic steatosis and insulin resistance in mice. Pharmaceutical Research. 32(4): 1200-1209.

Magalhaes, S., Guedes, R., Demuner, A. and Lima, E. 2008. Effect of coffee alkaloids and phenolics on egg-laying by the coffee leaf miner Leucoptera coffeella. Bulletin of Entomological Research. 98(5): 483-489.

Magalhães, S.T., Fernandes, F.L., Demuner, A.J., Picanço, M.C. and Guedes, R.N.C. 2010. Leaf alkaloids, phenolics, and coffee resistance to the leaf miner Leucoptera coffeella (Lepidoptera: Lyonetiidae). Journal of Economic Entomology. 103(4): 1438-1443.

Mahmoud-Awny, M., Attia, A.S., Abd-Ellah, M.F. and El-Abhar, H.S. 2015. Mangiferin mitigates gastric ulcer in ischemia/ reperfused rats: Involvement of PPAR- $\gamma$, NF-KB and Nrf2/ HO-1 signaling pathways. PloS one. 10(7): e0132497.

Mayer, J.L.S., Carmello-Guerreiro, S.M. and Mazzafera, P. 2013. A functional role for the colleters of coffee flowers. AoB Plants. 5: plt029.

Mondolot, L., La Fisca, P., Buatois, B., Talansier, E., De Kochko, A. and Campa, C. 2006. Evolution in caffeoylquinic acid content and histolocalization during Coffea canephora leaf development. Annals of Botany. 98(1): 33-40.

Murthy, P.S. and Manonmani, H. 2008. Bioconversion of coffee industry wastes with white rot fungus Pleurotus florida. Research Journal of Environmental Sciences. 2(2): 145-150.

Naidoo, N., Chen, C., Rebello, S.A., Speer, K., Tai, E.S., Lee, J., Buchmann, S., Koelling-Speer, I. and van Dam, R.M. 2011. Cholesterol-raising diterpenes in types of coffee commonly consumed in Singapore, Indonesia and India and associations with blood lipids: A survey and cross sectional study. Nutrition Journal. 10(1): 48.
Nair, K.P. 2010. Coffee. In: K.P. Prabhakaran Nair (Ed). The agronomy and economy of important tree crops of the developing world. Amsterdam. Elsevier.

Neuwinger, H.D. 2000. African traditional medicine: a dictionary of plant use and applications. With supplement: search system for diseases. Germany. Medpharm. Scientific Publishers, $589 \mathrm{pp}$

Noratto, G.D., Bertoldi, M.C., Krenek, K., Talcott, S.T., Stringheta, P.C. and Mertens-Talcott, S.U. 2010. Anticarcinogenic effects of polyphenolics from mango (Mangifera indica) varieties. Journal of Agricultural and Food Chemistry. 58(7): 41044112.

Ong, K.W., Hsu, A. and Tan, B.K.H. 2013. Anti-diabetic and antilipidemic effects of chlorogenic acid are mediated by ampk activation. Biochemical Pharmacology. 85(9): 1341-1351.

Paiva, E. and Machado, S. 2006. Colleters in Caryocar brasiliense (Caryocaraceae) ontogenesis, ultrastructure and secretion. Brazilian Journal of Biology. 66(1B): 301-308.

Pal, R., Chaudhary, M.J., Tiwari, P.C. Nath, R. and Pant, K.K. 2018. Pharmacological and biochemical studies on protective effects of mangiferin and its interaction with nitric oxide (NO) modulators in adjuvant-induced changes in arthritic parameters, inflammatory, and oxidative biomarkers in rats. Inflammopharmacology. Pp 1-9.

Patay, É.B., Bencsik, T. and Papp, N. 2016a. Phytochemical overview and medicinal importance of Coffea species from the past until now. Asian Pacific Journal of Tropical Medicine. 9(12): 1127-1135.

Patay, E.B., Nemeth, T., Nemeth, T.S., Filep, R., Vlase, L. and Papp, N. 2016b. Histological and phytochemical studies of Coffea benghalensis B. Heyne EX Schult., compared with Coffea arabica L. Farmacia. 64(1): 125-130.

Patay, É.B., Sali, N., Kőszegi, T., Csepregi, R., Balázs, V.L., Németh, T.S., Németh, T. and Papp, N. 2016c. Antioxidant potential, tannin and polyphenol contents of seed and pericarp of three Coffea species. Asian Pacific Journal of Tropical Medicine. 9(4): 366-371.

Qu, Y., Zhou, L. and C. Wang, C. 2017. Mangiferin inhibits IL-1 $\beta$ induced inflammatory response by activating PPAR $-\gamma$ in human osteoarthritis chondrocytes. Inflammation. 40(1): 52-57.

Rajendran, P., Rengarajan, T., Nandakumar, N., Ivya, H. and Nishigaki, I. 2015. Mangiferin in cancer chemoprevention and treatment: pharmacokinetics and molecular targets. Journal of Receptors and Signal Transduction. 35(1): 76-84.

Ramírez, N.M., Toledo, R.C.L., Moreira, M.E.C., Martino, H.S.D., dos Anjos Benjamin, L., de Queiroz, J.H., Ribeiro A.Q. and Ribeiro, S.M.R. 2017. Anti-obesity effects of tea from Mangifera indica L. leaves of the Ubá variety in high-fat diet-induced obese rats. Biomedicine \& Pharmacotherapy. 91: 938-945.

Ratanamarno, S. and Surbkar, S. 2017. Caffeine and catechins in fresh coffee leaf (Coffea arabica) and coffee leaf tea. Maejo International Journal of Science and Technology. 11(3): 211.

Rocha, L.W., Bonet, I.J.M., Tambeli, C.H., de-Faria, F.M. and Parada, C.A. 2018. Local administration of mangiferin prevents experimental inflammatory mechanical hyperalgesia through CINC-1/epinephrine/PKA pathway and TNF-a inhibition. European Journal of Pharmacology. 830: 87-94.

Rodrigues, F.A., Carré-Missio, V., Jham, G.N., Berhow, M. and Schurt, D.A. 2011. Chlorogenic acid levels in leaves of coffee plants supplied with silicon and infected by Hemileia vastatrix. Tropical Plant Pathology. 36(6): 404-408. 
Ross, I.A. 2007. Medicinal plants of the world, volume 3: Chemical constituents, traditional and modern medicinal uses, Springer Science \& Business Media.

Sadeghi Ekbatan, S., Li, X.-Q., Ghorbani, M., Azadi, B. and Kubow, S. 2018. Chlorogenic Acid and Its Microbial Metabolites Exert Anti-Proliferative Effects, S-Phase Cell-Cycle Arrest and Apoptosis in Human Colon Cancer Caco-2 Cells. International Journal of Molecular Sciences. 19(3): 723.

Sadhukhan, P., Saha, S., Dutta, S. and Sil, P.C. 2018. Mangiferin ameliorates cisplatin induced acute kidney injury by upregulating Nrf-2 via the activation of PI3K and exhibits synergistic anticancer activity with cisplatin. Frontiers in Pharmacology. 9.

Saha, S., P. Sadhukhan, K. Sinha, N. Agarwal and P. C. Sil. 2016. Mangiferin attenuates oxidative stress induced renal cell damage through activation of PI3K induced Akt and Nrf-2 mediated signaling pathways. Biochemistry and Biophysics Reports. 5: 313-327.

Salgado, P.R., Favarin, J.L. Leandro, R.A. and de Lima Filho, O.F. 2008. Total phenol concentrations in coffee tree leaves during fruit development. Scientia Agricola. 65(4): 354-359.

Sanchez, P.M., Pauli, E.D., Scheel, G.L., Rakocevic, M., Bruns, R.E. and Scarminio, I.S. 2018. Irrigation and Light Access Effects on Coffea arabica L. Leaves by FTIR-Chemometric Analysis. Journal of the Brazilian Chemical Society. 29(1): 168-176.

Sharifi-Rad, J., Salehi, B., Stojanović-Radić, Z.Z., Fokou, P.V.T., Sharifi-Rad, M., Mahady, G.B., ... Iriti, M. 2017. Medicinal plants used in the treatment of tuberculosis Ethnobotanical and ethnopharmacological approaches. Biotechnology Advances. https://doi.org/10.1016/j. biotechadv.2017.07.001.

Shi, H., Shi, A., Dong, L., Lu, X., Wang, Y., Zhao, J., Dai, F. and Guo, X. 2016. Chlorogenic acid protects against liver fibrosis in vivo and in vitro through inhibition of oxidative stress. Clinical Nutrition. 35(6): 1366-1373.

Shi, W., Deng, J., Tong, R., Yang, Y., He, X., Lv, J., Wang, H., Deng, S., Qi, P. Zhang, D. and Wang, Y. 2016. Molecular mechanisms underlying mangiferin-induced apoptosis and cell cycle arrest in A549 human lung carcinoma cells. Molecular Medicine Reports. 13(4): 3423-3432.

Silva, M. d. C., Várzea, V., Guerra-Guimarães, L., Azinheira, H.G., Fernandez, D., Petitot, A.-S., Bertrand, B., Lashermes, P. and Nicole, M. 2006. Coffee resistance to the main diseases: leaf rust and coffee berry disease. Brazilian Journal of Plant Physiology. 18(1): 119-147.

Sridevi, V. and Giridhar, P. 2016. Variations in diterpenes-cafestol and kahweol content in beans of robusta coffee grown at different altitudes. Proceedings of the National Academy of Sciences, India Section B: Biological Sciences. 86(2): 291-297.

Stashenko, E.E., Martínez, J.R., Cárdenas-Vargas, S., SaavedraBarrera, R. and Durán, D.C. 2013. GC-MS study of compounds isolated from Coffea arabica flowers by different extraction techniques. Journal of Separation Science. 36(17): 29012914.
Talamond, P., Mondolot, L., Gargadennec, A., de Kochko, A., Hamon, S., Fruchier, A. and Campa, C. 2008. First report on mangiferin (C-glucosyl-xanthone) isolated from leaves of a wild coffee plant, Coffea pseudozanguebariae (Rubiaceae). Acta Botanica Gallica. 155(4): 513-519.

Tesfaye, K., Govers, K., Bekele, E. and Borsch, T. 2014. ISSR fingerprinting of Coffea arabica throughout Ethiopia reveals high variability in wild populations and distinguishes them from landraces. Plant Systematics and Evolution. 300(5): 881-897.

Thomas, V. and Dave, Y. 1989. Histochemistry and senescence of colleters of Allamanda cathartica (Apocynaceae). Annals of Botany. 64(2): 201-203.

Trevisan, M.T., de Almeida, R.F., Soto, G., Virginio Filho, E.D.M., Ulrich, C.M. and Owen, R.W. 2016. Quantitation by HPLC-UV of Mangiferin and Isomangiferin in coffee (Coffea arabica) leaves from Brazil and Costa Rica after solvent extraction and infusion. Food Analytical Methods. 9(9): 2649-2655.

Ukers, W.H. 1935. All about coffee, Library of Alexandria.

Van Wyk, B.-E. 2015. A review of commercially important African medicinal plants. Journal of Ethnopharmacology. 176: 118134.

Várzea, V. and Marques, D. 2005. Population variability of Hemileia vastatrix vs. coffee durable resistance. Durable resistance to coffee leaf rust. UFV, Viçosa, p. 53-74.

Vega, F.E., Posada, F. and Infante, F. 2006. Coffee insects: ecology and control. Encyclopedia of Pest Management. 1-4.

Vyas, A., Syeda, K., Ahmad, A., Padhye, S. and Sarkar, F.H. 2012. Perspectives on medicinal properties of mangiferin. Mini Reviews in Medicinal Chemistry. 12(5): 412-425.

Woldeab, B., Regassa, R., Alemu, T., and Megersa, M. 2018. Medicinal plants used for treatment of diarrhoeal related diseases in Ethiopia. Evidence-Based Complementary and Alternative Medicine. Vol 2018, Article ID 4630371, 20 pp.

Yamagata, K., Izawa, Y., Onodera, D. and Tagami, M. 2018. Chlorogenic acid regulates apoptosis and stem cell markerrelated gene expression in A549 human lung cancer cells. Molecular and Cellular Biochemistry. 441(1-2): 9-19.

Yan, Y., Liu, N., Hou, N., Dong L. and Li, J. 2017. Chlorogenic acid inhibits hepatocellular carcinoma in vitro and in vivo. The Journal of Nutritional Biochemistry. 46: 68-73.

Yoshimi, N., K. Matsunaga, M. Katayama, Y. Yamada, T. Kuno, Z. Qiao, A. Hara, J. Yamahara and H. Mori. 2001. The inhibitory effects of mangiferin, a naturally occurring glucosylxanthone, in bowel carcinogenesis of male F344 rats. Cancer Letters 163(2): 163-170.

Zhang, B. P., J. Zhao, S.-s. Li, L.-j. Yang, L.-I. Zeng, Y. Chen and J. Fang. 2014. Mangiferin activates Nrf2-antioxidant response element signaling without reducing the sensitivity to etoposide of human myeloid leukemia cells in vitro. Acta Pharmacologica Sinica 35(2): 257.

Zheng, X.-Q. and H. Ashihara. 2004. Distribution, biosynthesis and function of purine and pyridine alkaloids in Coffea arabica seedlings. Plant Science 166(3): 807-813. 